\title{
Post-Revolution Urban Landscape: Transforming Public Spaces after 2011 Revolutions
}

\author{
By Ana Medina Gavilanes*
}

\begin{abstract}
New York - Zuccotti Park, Cairo - Tahrir Square, Istanbul - Gezi Park, London - St. Paul' Cathedral, Madrid - Puerta del Sol; these cities and places have acquired new significances after 2011, a year in which revolutions represent the power that people and public spaces have in societies. Unlike previous revolutions, these are germinated in the virtual space with such intensity that they connect simultaneously plazas, squares and streets around the world. This momentum represents, in the contemporary scope, one of the most important aspects of the future city's dynamics, the transformation of the urban landscape. Right after the development of these revolutions, local governments were aware of the power these events symbolized, for they started to apply quickly urban regulations that had been popular in New York, but to some extent hidden from the public sphere, namely the trading of public space to private investors. Planning departments became suspects and mediators, public assets were rapidly privatized and contemporary cities faced rampant land speculation. This legal figure for public space transaction is called Privately Owned Public Spaces - POPS. Patterns of ownership and control based on values of private property have been inflexible, a state in which even the public attention could do little to shift it. In this urban situation, the sense of public rises as a matter, which engages as a whole the public life - law, speech, representation, policy, distribution, and economics. These Privately Owned Public Spaces use design as a way of considering, representing, and constructing relationships between people and space, in a sphere of general control and surveillance.
\end{abstract}

\section{Introduction}

The Privatization of Public Space - Origins in New York

Zuccotti Park in New York, Tahrir Square in Cairo, Gezi Park in Istanbul, Puerta del Sol in Madrid, Paternoster Square in London, HSBC Plaza in Hong Kong, Euromaidan in Kiev, 101 Tower in Taipei, City Square in Melbourne, Syntagma Square in Athens... This endless list shows numerous spaces and events that befit catalyst factors when taking decisions about the transformation of the cities' public landscape. The 2011 Revolutions (the Occupy Movement, los Indignados, the Arab Spring...) have become a strong force for changing the global urban landscape physically, virtually and legally. These events have brought to light the little discussion and knowledge that there has been about how public spaces should be in the contemporary city, but they have also

* PhD Student, Polytechnic University of Madrid, Spain and Goldsmiths, University of London, UK. 
showed a shocking fact: these revolutions display a noiseless stabilized situation over the public sphere, the privatization of public spaces.

Yet, the privatization of public land is not a new urban model, it is a concept that was born in 1916 in New York with the "Zoning Resolution." This normative intends to stop the settlement of bulk buildings that cause suppression of air and light on the ground level. It is precisely the Occupy Movement and its global outreach that revealed this normalized situation in many cities around the world, stemming from New York. This legal structure is named "Privately Owned Public Spaces." Privately Owned Public Spaces (from now onwards POPS) fall into the following categories and definitions:

1. A plaza, arcade, or other outdoor or indoor space provided for public use by a private office or residential building owner in return for a zoning concession.

2. A type of public space characterized by the combination of private ownership and zoning-specified public use.

3. One of 525 or so plazas, urban plazas, residential plazas, public plazas, elevated plazas, arcades, through block arcades, through block gallerias, through block connections, covered pedestrian spaces, sidewalk widenings, open air concourses, or other privately owned public spaces specifically defined by New York City's Zoning Resolution and accompanying legal instruments.

4. Law's oxymoronic invention. ${ }^{1}$

In the early 1900s, the industrial revolution set up a series of construction systems that allowed the building of higher skyscrapers. Yet, there was a critical people's reaction to the construction of buildings as they were preventing light and air from reaching the ground floor. In a parallel operation, there was a kind of competition to have the tallest building in the city, as there were no legal norms, restrictions or regulations besides the limits of construction systems. Thus, in 1916 the New York Planning Commission wrote the first urban regulations in which height district rules determined the relationships between building massing and the public realm of streets and sidewalks. ${ }^{2}$ If the building covered no more than $1 / 4$ parts of the whole plot, there were no height restrictions at all, as it was assumed that the building would be slim and tall and would not interfere with light and air attaining the ground level. ${ }^{3}$ However, this initial regulation pointed at the height of buildings, and not to the conditions of the ground floor; hence, most of the new edifices covered their plots completely and no space was left open. Only in 1958, when the Seagram Building designed by Mies van der Rohe was completed (Figure 1), did the building industry-including critics, urban planners, and architects-see the potentialities

1. POPS, “APOPS, Advocates for Privately Owned Public Space,” APOPS (2012).

2. Christian Dimmer, "Changing Understanding of New York City's Privately Owned Public Spaces," SUR (2013): 8.

3. Jerold S. Kayden, The New York City Department of City Planning. Privately Owned Public Space: The New York City Experience (New York: John Wiley \& Sons, Inc, 2000). 
of the ground floor value. Three years later, the City's Zoning Regulation was introduced based on this iconic building model.

A Floor Area Ratio (FAR) defined the total floor area that a building could have in a specific zoning lot in relation to the area of the building plot. ${ }^{4}$

This is: for every square meter of POPS developers provided to the city, they were rewarded with up to 10 square meters of FAR bonus for their buildings with a limit of $20 \%$ in their size. Thus, many new buildings constructed in New York between the 1960s and 1970s included a POPS model in their designs, denoting a successful urban regulation in New York.
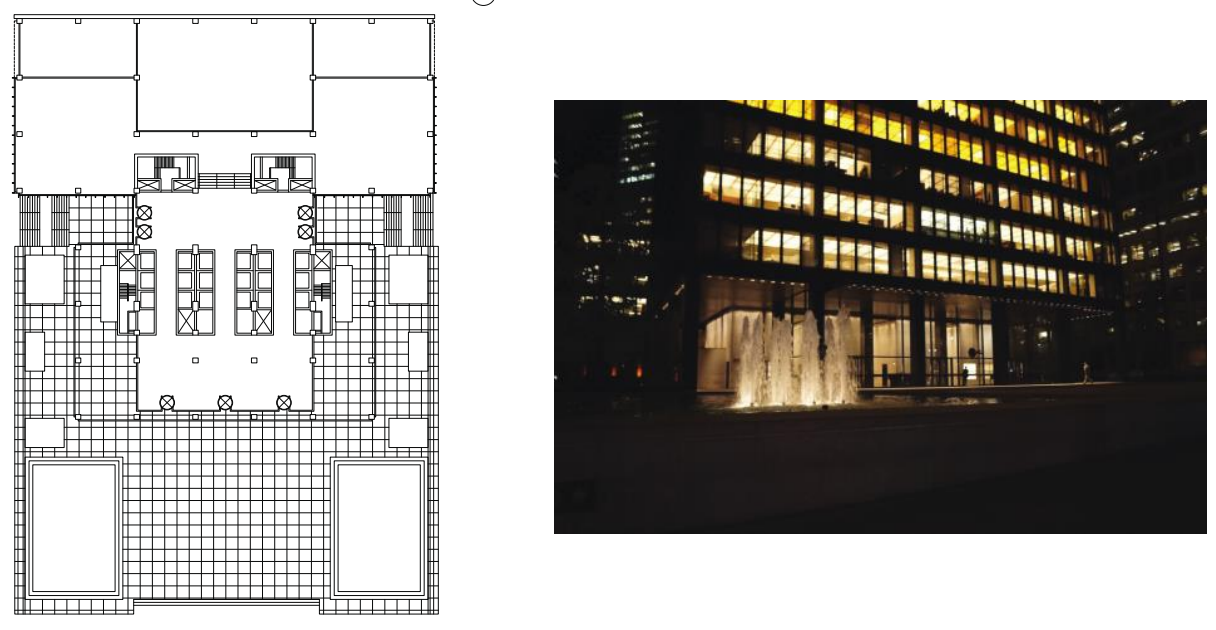

Figure 1. Seagram Building. Left: Ground Floor Plan. Right: Entrance Plaza. Source: Author.

Zoning amendments were introduced in these regulations constantly, especially over the design and requirements that POPS included. The Zoning Resolution indicated that there should be an allowable height of plazas above and below an abutting sidewalk, movable chairs and fixed benches, a minimum number of trees, planter ledges, and so on. In terms of accessibility, the regulation specified that these must be available: "to the public at all times for the use and enjoyment of a large number of people, ", therefore POPS were considered to be living rooms of open spaces. Nevertheless, these design parameters were directly affected by the 70 s crisis, because the City Hall needed to reactivate the city's economy. In doing so, they decided to give more benefits to developers by offering them special permissions to build higher edifices, having fewer environmental requirements in their constructions, giving them

4. Kayden, The New York City Department of City Planning. Privately Owned Public Space: The New York City Experience, 2000.

5. Ibid. 
freedom on designing POPS, and reducing procedures in process reviews. As a consequence, there was another wave of bulkier buildings appearing in Manhattan in the 1980s (Figure 2), and by the 1990s, the Zoning Resolution was particularly complex and difficult to understand even for specialists in the field.

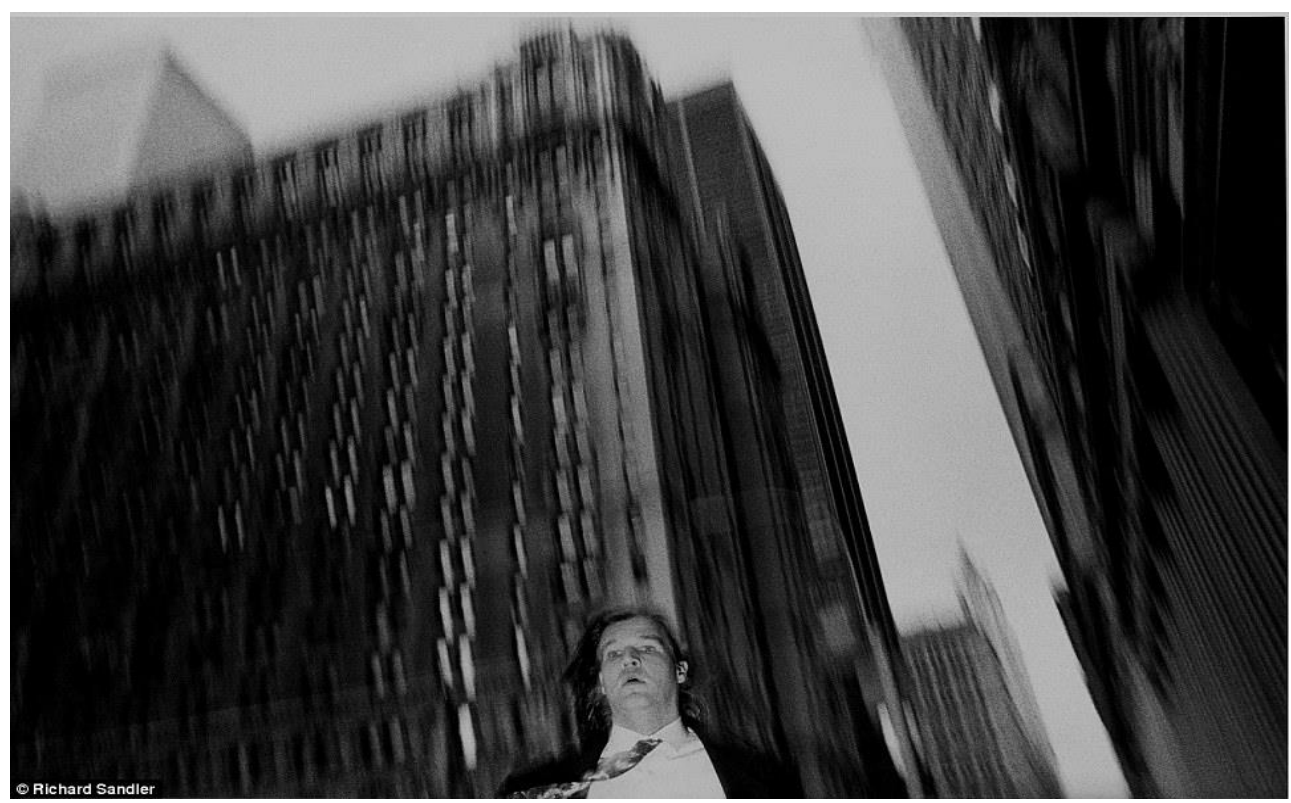

Figure 2. The Streets of Manhattan: A suited Man is captured on Camera as He Walks Near Broadway and Wall Street. Circa 1987. Photographer: Richard Sandler.

Source: Greig, Alex, "The city where the greed was good," Daily Mail, 10 November 2013. http://dailym.ai/2vUSEmp.

\section{The Transition of New POPS in New York}

By the late '90s, the relationship between POPS and New York was blurred, confused and diffused, and it was at this point that Jerold Kayden ${ }^{6}$ in collaboration with the New York City Department of Planning and the Municipal Art Society, worked on research about the current state of POPS created in New York from 1961 to 2000. The study named "Privately Owned Public Space: the New York Experience" indicates that in general, the city and the public at large do not have accurate information about these POPS, their legislation, data, use or design. In numbers, the research quantifies 503 POPS, in a covered area of 300 thousand square meters - nearly the $10 \%$ of Central Park area and a media of 1400 square meters. 3\% of this area is qualified as space for people from inside and outside the neighbourhood, $13 \%$ is categorized as a neighbourhood space, $21 \%$ as hiatus space for brief stopovers, and $18 \%$

6. Jerold Kayden, professor of Urban Planning and Design at the Harvard University Graduate School of Design. He served as Co-Chair of the Department of Urban Planning and Design and as Director of the Master in Urban Planning Degree Program. 
works only for mobilizing as pedestrian circulation. $41 \%$ of the total area is described as marginal spaces "without any measurable public use."7

Theoretically, POPS in New York remain in property but must be usable by all members of the public at any time. Nonetheless, this survey indicates that receiving benefits does not necessarily provide solutions for the city's lack of public spaces. This is the case of the Lincoln Center Atrium in New York, the "David Rubenstein Atrium," which is a POPS re-designed by the architects TWBTA in 2009, and serves mainly as a ticketing facility for the Lincoln Center. In the place's description website it reads:

- A vibrant community-gathering place to linger in and enjoy, with plenty of places to sit

- A venue for free weekly performances

- A resource for discount tickets to available Lincoln Center performances

- Food service from Chef Tom Colicchio's witchcraft café

- A staffed Tour and Information Desk

- Restrooms

- A destination for free Wi-Fi access ${ }^{8}$

Before the re-design and construction of the David Rubenstein Atrium, there was formerly the "The Harmony Atrium," a City Council property where people used to gather freely at any time. It was an indoor public space that extended from Broadway to Columbus Avenue between $62^{\text {nd }}$ and $63^{\text {rd }}$ streets. It attracted many people who used its rocks-climbing wall, as well as homeless people who sought shelter during winter. For the new project, the architects TWBTA expressed their desire to create a hot spot outside the Lincoln Center, where people could buy a day-of-show ticket and/or sip coffee and cocktails before or after the Center performances. Tom Dunn, director of the David Rubenstein Atrium, indicated that the project was a "true urban oasis, a theatrical garden that's got these wonderful architectural signature items, 25foot-high vertical gardens, floor to ceiling fountains, and a 97-foot-long installation in felt by the Dutch textile artist Claudy Jongstra - all designed to be a welcoming space for the public." "The Atrium project was part of the $\$ 1.2$ billion Lincoln Center redevelopment and has an area of 650 square meters ${ }^{10}$ (Figure 3). Despite this, what was initially meant to be used by all is in fact used only by a certain group of the public, i.e. people who assist the Centre's performances, visitors, or tourists. ${ }^{11}$

7. Ibid.

8. Lincoln Center, David Rubenstein Atrium. http://bit.ly/2xm1Eo0.

9. WQXR, An Atrium Gets an Extreme Makeover, http://www.wqxr.org/\#!/story/2331-anatrium-gets-an-extreme-makeover/.

10. Theresa Agovino, Lincoln Center completes $\$ 1.2 B$ redevelopment. Crain's New York Business. October, 2012.

11. In a visit to The Lincoln Center in 2012, I decided to spend one day and night at the Atrium. The space was used by freelancers but mainly tourists and people that stopped there for a drink, to get tickets for the Centre's performances or exhibitions, or to meet people before 

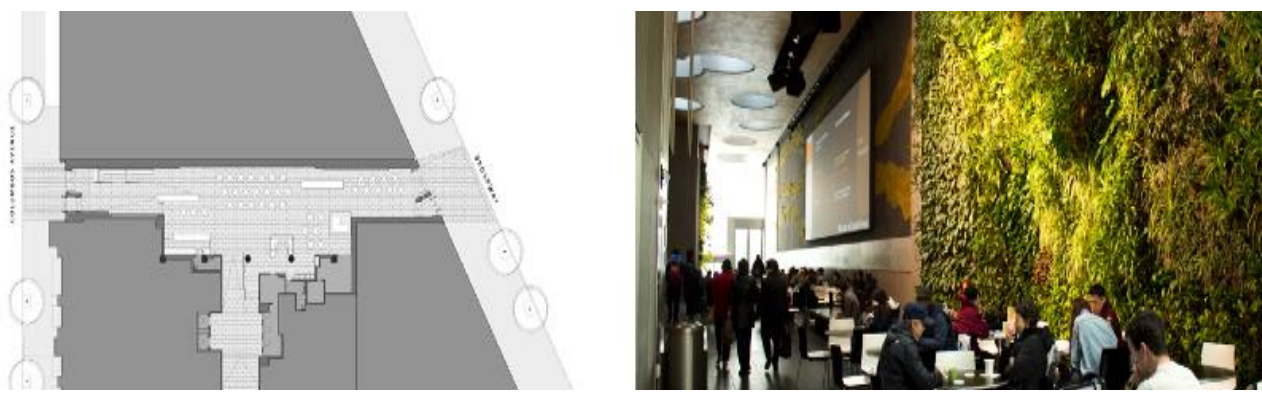

Figure 3. David Rubenstein Atrium at Lincoln Center. Left: Ground Level Plan. Right: Interior View.

Source: Tod Williams Billie Tsien. http://bit.ly/2xmBlhn.

\section{Privatization Legacy of 2011 over the Architectural Urban Landscape}

"The First Amendment protections do not really apply when the owners of a space are non-governmental.",12

Since 1961, public land in New York has been transferred to private investors legally. Nevertheless, it was only after the 2011 revolutions that this practice was pushed massively over major capital cities around the world. At this point, it is necessary to understand the side of the developer in this situation. The rationale is simple: the value of the incentive is equal or exceeds the cost of the given public space. ${ }^{13}$ This financial mechanism incentivizes and attracts developers by giving them more built area (the higher the building, the more expensive the property on upper floors is), tax benefits to developers, and providing a POPS that increases the income on their properties. Large parts of capital cities have been redeveloped as privately owned estates, extending corporate control over squares and thoroughfares; it looks like the changing scale of privatisation is the result of the 2011 Revolutions. As the Occupy protests highlighted, private owners can refuse the right of entry to members of the public, closing off swaths of the city. ${ }^{14}$ This is a vision of a society in which people work and shop. At times when people are not working or shopping, they might go to restaurants or attend to a show or sport's spectacle ${ }^{15}$ (Figure 4). If these private public spaces are invading the public landscape of cities, could it be possible to have Publicly Owned Private Spaces?

entering to the Centre. After talking to waiters, bartenders and security guards, they said among other things - there have not been issues with homeless people or any spontaneous action that could be violent or uncomfortable. However, they said sometimes there have been performances that involved art, music, or dance.

12. Francis Reynolds, After Zuccotti Park: Seven Privately Owned Public Spaces to Occupy Next, http://bit.ly/2jrsMMX.

13. Kayden, The New York City Department of City Planning. Privately Owned Public Space: The New York City Experience, 2000.

14. Charles Wolfe, When Policy is Defied: Occupy Wall Street and the Shapes of Avoidance, http://theatln.tc/2y0f06w (2011).

15. Naomi Colvin, Occupy Activist. http://bit.ly/1t2xdYQ. 
(1)
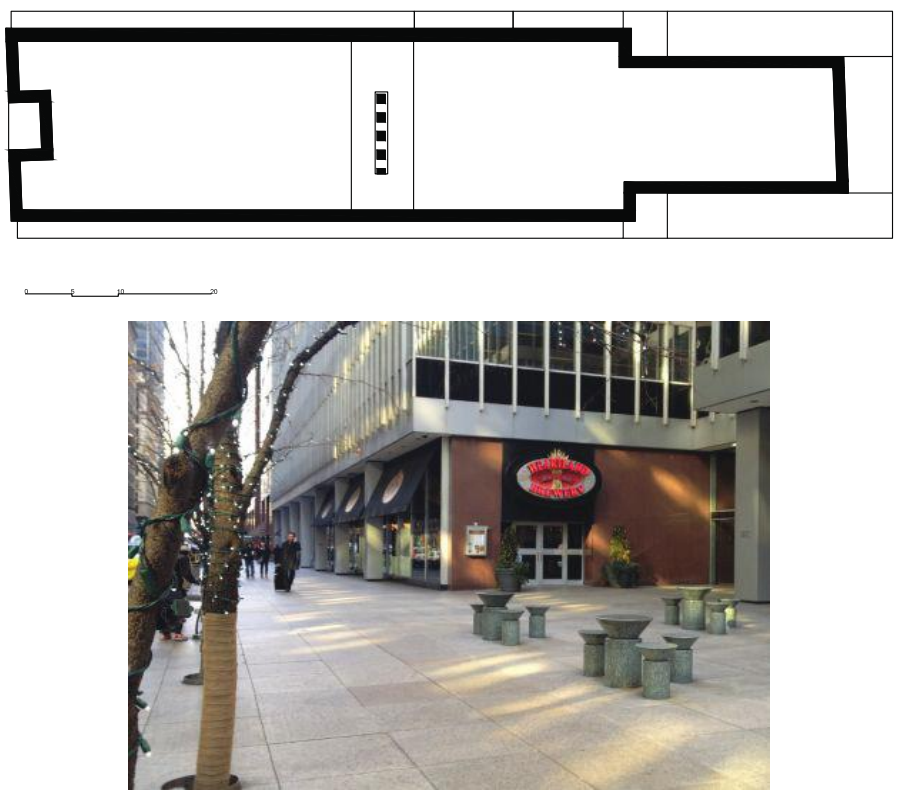

Figure 4. 1285 Sixth Avenue. Top: Ground Floor Plan. Bottom: Exterior View. Source: Google Maps View.

After the 2011 Revolutions, POPS' owners in New York create their own Rules of Conduct. This document indicates whether to allow or prohibit activities, social behaviours, and use of their land. The signs range from simple rules like "No Smoking" to exhaustive catalogues of expected behaviour in this space.

"[A "Rule of Conduct"] sign shall not prohibit behaviours that are consistent with the normal public use of the public plaza such as lingering, eating, drinking of non-alcoholic beverages or gathering in small groups. No behaviours, actions, or items may be listed on such sign that are otherwise illegal or prohibited by municipal, State, or Federal Laws." 16

Rules of Conduct signs in POPS specify prohibitions in four categories: movement (i.e. no skateboarding); sound (i.e. no radio-playing); illegal activity (i.e. no distribution of controlled substances); and use of space (i.e. no sleeping). After the OWS occupation, there has been a significant increment in the amount of POPS' new regulations, which essentially limit all permitted activities to passive uses. These situations rely on the inert state of public spaces; they are seen as refuges from urban life rather than places of engagement and surprise. ${ }^{17}$ In his research, Jerold Kayden cites the origin of POPS in the 1958

16. Kayden, The New York City Department of City Planning. Privately Owned Public Space: The New York City Experience, 2000.

17. Drew Austin, Overprogrammed Cities (2012). 
draft Zoning Resolution, which matter-of-factly recites the rationale for incentivizing public space through zoning:

"In order to bring more light and air into the streets surrounded by tall buildings, as well as to create more usable open space, a bonus device has been established to encourage the setting back of buildings from the street line." $" 18$

The original bonus was an incentive to provide only plazas in front of the new buildings, an urban situation that is traced back to the 1961 draft's reliance on the Corbusian model of the tower in the park. This model was later replaced by contextualists and their street-wall model. According to the City's own analysis, the Zoning Resolution never expressly defined which limits the owners could apply, if any, upon public use. Nonetheless, after 2011 landlords planned to revamp the rules governing privately owned parks, including removing a requirement that POPS must be open 24 hours a day. Some of these urban measures seem to be desperate for the purpose to discourage, deter and crack down on any social protests. ${ }^{19}$ These are some of the new regulations:

- No camping or erection of tents

- No snoozing in public

- No umbrellas

- No open flames

- No lying down on the ground or on benches

- No tarps or sleeping bags

- No obstructing the pedestrian walkway

- No private belongings in public space

- Unaffordable fees

- No potties

- No masks

- Mass arrests, excessive force

This update on the Zoning Resolution seeks to sanction protesters and involve them in a jungle of laws, regulations and civil ordinances that many times are far from what is going to be punished. ${ }^{20}$ This is a softer repression, not so much in its effects as in its way of being exercised. It locates the protester in a bureaucratic tether by increasing the number of regulations and policies; however, without going deeper in this system, it is a structure that obstructs the basic rights of citizens to protest. Hence, should owners be allowed to prohibit use by organized large groups? Are passive activities like quiet

18. Planning, Department of City, Zoning Resolution (New York, 2015).

19. Ryan Williams, New Obstacles for Occupy Chicago? (2011); Douglas Woodward, Rules of Conduct (2012).

20. Rania Khalek, 12 Most Absurd Laws Used to Stifle the Occupy Wall St. Movement Around the Country (2011). 
conversations or sharing lunchtime to become the only approved behaviours? Should all POPS' owners have the right to dictate what to do in their spaces? Let's not forget that POPS were meant to create and contribute meaningful life to the city, not only by assuring that those spaces are provided as legally promised, but also by encouraging improvements, activities, and public educational opportunities.

\section{The Space of Thwarted Revolutions}

Paternoster Square, London

The eruption of the Occupy Movement is and will remain one of the most significant moments of contemporary history. It was a decentralized and horizontal social multi structure materialized on the public space - physically and digitally that activated new dynamics within the public sphere. This phenomenon was quickly extended around the world. Nevertheless, in London the situation was particularly different from other Occupy protests. When the movement started to emerge, it was rapidly controlled not by authorities but by private security guards. Protesters intended to host a sit-in at Paternoster Square, the outside plaza of the London Stock Exchange building and symbol of the capital system in London but they could not even walk close to its entrances. The reason: the square is a private property. Anecdotally, it was repeatedly described as a 'public space' when it was under construction. ${ }^{21}$

The creation of Paternoster Square revealed a certain promiscuity in changing hands between owners for more than twenty years. In the 1980s, the city started a plan to demolish all the post-war buildings. At that time, the plaza was the property of the Church Commissioners, but in 1985 the Mountleigh Group took a 250-year lease on the core of the site and organised an urban planning competition. ${ }^{22}$ Paternoster Square is located immediately north of St Paul's Cathedral in the City of London. It was bombed in 1942 and re-built in 1961. Because of its resemblance, symbolism, location, and historical force, the completion brought big architecture firms such as Richard Rogers, Norman Foster, Arata Isozaki, Richard MacCormac, James Stirling, Arup Associates and Skidmore Owings \& Merrill. Arup's postmodern project won the competition but the Prince of Wales and his ten-architect team presented a new project: a neoclassical concrete mega-structure with an underground shopping mall. However, the Prince's idea and Arup's project were revoked. As the public was drizzling in ideas, the project was directly pointed to William Whitfield, a British architect, resulting in its current curate's egg (Figure 5).

21. Isabelle Koksal, “Activist Intervention: Walking in the City of London,” in Occupy! A Global Movement (ed.) Jenny Pickerill, John Krinsky, Graeme Hayes, Kevin Gillan and Brian Doherty (Oxon: Routledge, 2015).

22. Jonathan Glancey, "It's a jumble out there." The Guardian (3 November 2003). 


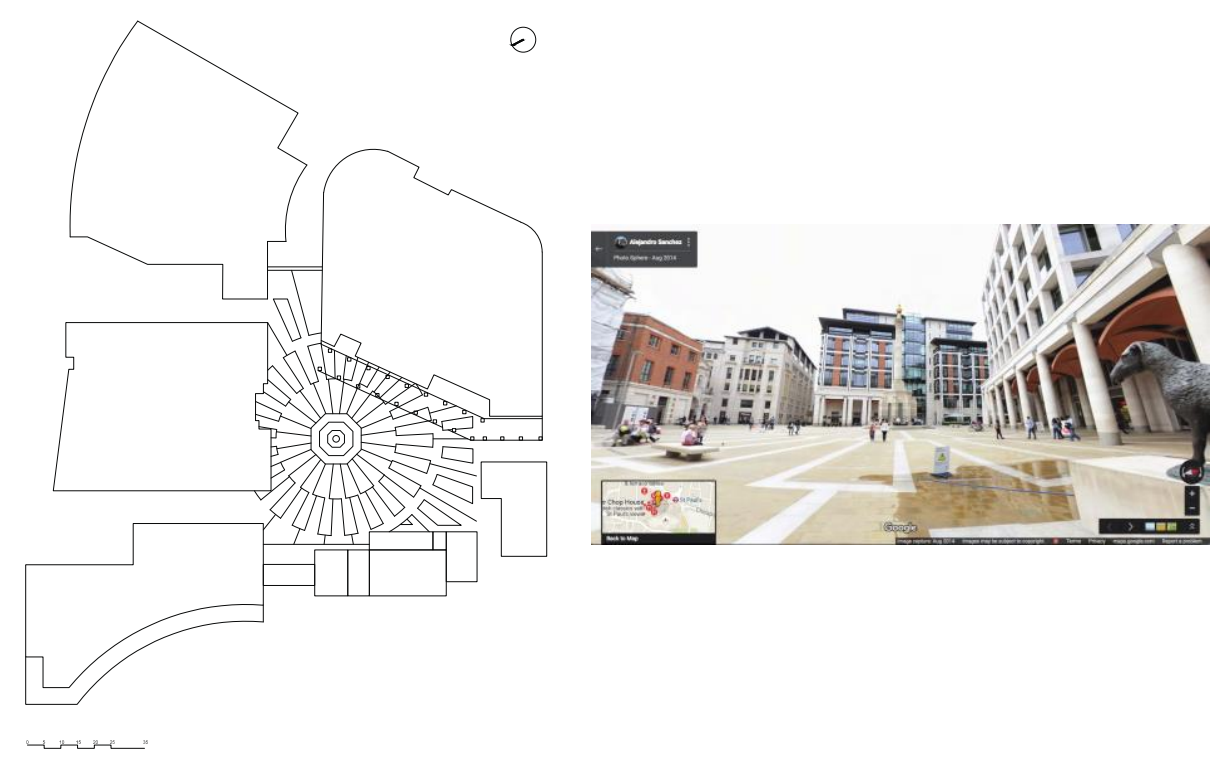

Figure 5. Paternoster Square. Left: Ground Floor Plan. Right: Entrance. Source: Google Maps View.

Paternoster Square (from the latin pater noster: Our Father) is surrounded by an obese mass of offices and bulky buildings where Whitfield designed a state of separation between "classicists" and "modernists." These buildings are crudely hulking: six and seven floors high, with a colonnade at the ground level and finished in a mix of brick and stone. The pedestrian alleys leading to Ave Maria Lane are narrow, classical-lite shops, flats, and offices, all around this pedestrian precinct that invokes only the displacement, not the permanence. There is an extensive use of stone but on the other hand there is no water supply, vegetation spots, or confortable seating, making the square cold and hard in winter and hot and dazzling in summer. By 2003, the project was completed with an investment of $£ 120$ millions and currently belongs to Mitsubishi Estate $\mathrm{Co}^{23}$ (Figure 6).

The owners of Paternoster Square were able to issue a court injunction that banned protesters from using the square for their protest before the occupation could have taken place, as they felt the threat of a new Occupy Wall Street or Arab Spring momentum. ${ }^{24}$ Immediately, a sign was placed in the main access to the Square; it reads (Figure 7):

"Paternoster Square is private land. Any general licence to the pubic to enter or cross this land is revoked forthwith. There is no implied or express permission to enter the premises or any part without consent.

23. Ibid.

24. Koksal, “Activist Intervention: Walking in the City of London,” 2015. 
Any such entry will constitute a trespass. Limited consent is hereby given, but can be revoked at any time, for entry on to the accessible parts of the square, solely for access to the offices, retail units and leisure premises for genuine building, retail and leisure purposes. Visitors must at all times comply with the directions given by our security personal."

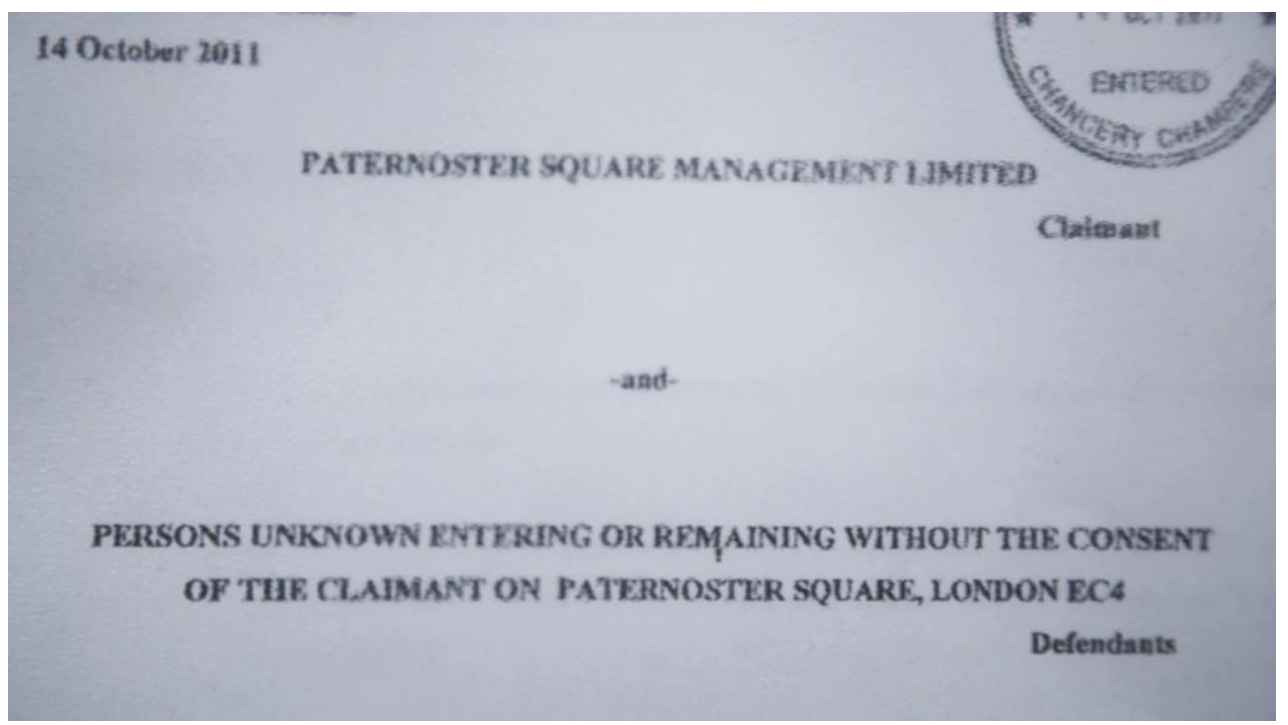

Figure 6. Paternoster Square Property Sign.

Source: Author.

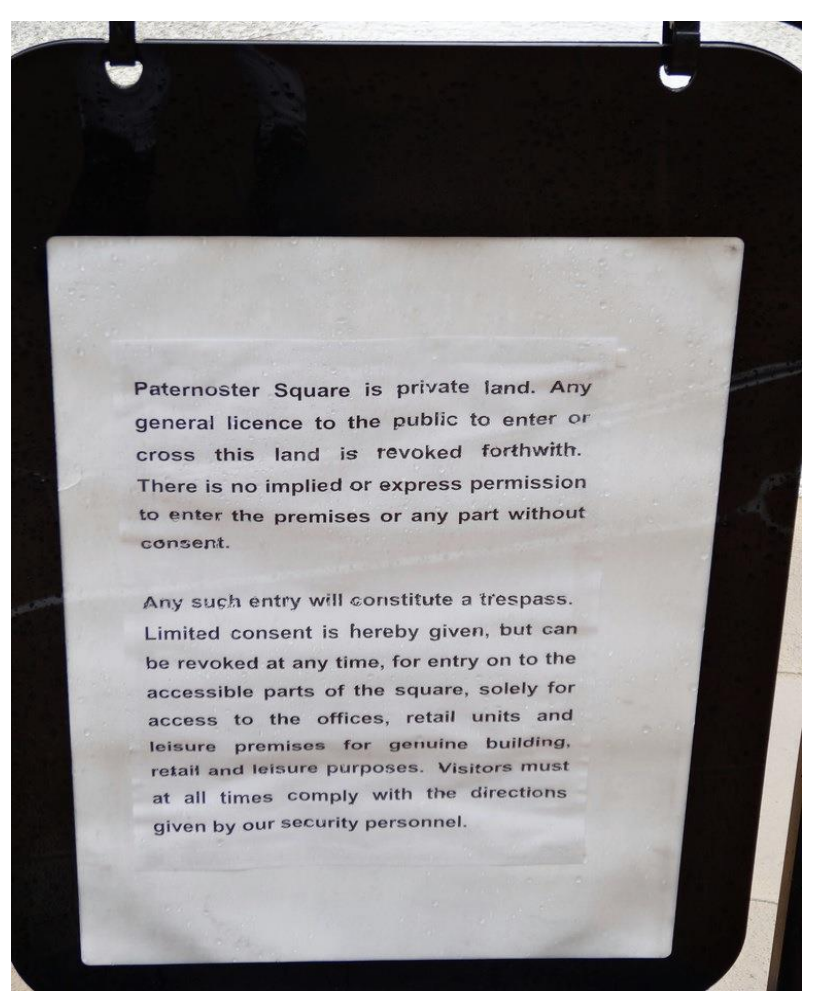

Figure 7. Paternoster Square Private Land Sign. Source: Author. 
Nonetheless, protesters did find a public space to occupy in London: a small triangular plot outside St. Paul's Church. Yet, this was also not a truly public space as it belonged (and still does) to the Church of England and the Corporation of London. Occupy London's thwarted intentions to occupy Paternoster Square proved the power that corporations in London have had when regulating and deciding what, how, who and when people could use the public spaces that were really private.

\section{Cairo and the New Cairo}

The eighteen days of the revolution in Tahrir Square created new urban situations for relations among the space, the body, the language and the law. Indeed, the Occupy movement took as reference the structure of the occupation at Tahrir Square - including the horizontality of the movement, the selfconstruction and production, the self-governance and the social relations. It happened first in Cairo. As the revolution succeeded in overthrowing Mubarak's regime, it proved the force people and public spaces have when forming new gatherings in the city and creating new urban situations. Thus, not only the Egyptian government, but also every government, around the world saw the potential when people and public space merge on the same plane.

Four years later, in March 2015, president Fattah al-Sisi announced the construction of a new capital city, still officially nameless but publicly called The Capital Cairo. Using $£ 30$ billion of private investment, the 700 squarekilometre project includes 21 residential districts, 1250 mosques and churches, and 1.1 million houses. ${ }^{25}$ For the government, this new capital project resembled a symbol of national renewal after four years of political destabilization and deep social division. This farcical project is intending to abandon the current 20 million-inhabitant capital, Cairo, to its own luck, obscuring it from any kind of innovative planning; and on the other side, it intends to create a five million person city twice the size of the current Cairo. This project represents an extreme machine of land privatization.

\section{The Global Corporate Public Architecture}

This machine, the privatization of public space, considers private agents the substitutes of the state's duties. The city is in a progressive privatization when facing the fact that local governments do not have the money to provide, create or maintain public spaces. However, that is not really the problem. There are POPS that are well designed and respond to people and zone's needs. Nevertheless, as it has been seen, these cases are more an exception than a norm. The co-production of public space incorporating private actors in its construction is a phenomenon that has been parallel to the implementation of neoliberal ideas in the economy of states. It is a phenomenon that has been

25. The Capital, Cairo, http://thecapitalcairo.com/. 
established in urban centres of capital cities. Progressively, cities are the scenarios for neoliberal performances using ready-made public spaces.

These situations are not just urban corps; "it is instead a global corporate subject. The situation enforces innovation by people and communities, even if they do not necessarily become powerful in the process, they produce components of a city" ${ }^{26}$ that would enable new spaces. City planning has become adept at the delivery of high quality public realms as part of large-scale private developments combining office, retail, residential and leisure. They all have in common that they need public spaces. The planning system has not caught up with the fact that these new and needed public spaces are often subject to private management, and more importantly, to private requirements. ${ }^{27}$ This situation can lead them to pursue control of public areas and to apply codes of conduct that are, for many people, inappropriately restrictive. Certainly, there may be reasonable concerns around liability, health and safety, but many of these restrictions range from the precautionary and unnecessary to the total exclusion of all but a privileged few - hardly in the spirit of democracy and inclusion.

Indeed, POPS so different and distant as Seattle or Hong Kong have nearly identical image and use, converting the urban landscape into a worldwide homogeneous landscape. Developers have been using a copy-paste strategy from New York's POPS without attending to the real needs, context, and reality of their locations and societies, and further on, the future planning. Local history and stories, planning cultures, actor networks, and spatial conditions have not been taken into account when designing and locating POPS: fixed chairs and tables, granite pavement, certain number of trees, bushes on the perimeter, long rows of concrete or stone benches; the design of plazas and the urban furniture establish a guide of allowed activities and individual and collective behaviour. Another factor is the private security, the excess use of CCTV cameras, and fences; these elements that include a security connotation, under this context initiate a violent character as they become part of a control machine. Foucault in his declaration about power and public space raises this combination as a vital role of the city, as an institutionalisation of the body that could be controlled and organized. ${ }^{28}$

The consequences of multiplying and expanding POPS affect the personal psyche and the ability of protest. They make people feel too monitored, too controlled; they eradicate most of the possible collective spontaneous actions and prevent communal activities from simply unfolding. Moreover, the geographer David Harvey indicates, "the freedom to make and remake our cities and ourselves is (...) one of the most precious yet most neglected of our

26. Saskia Sassen, Who owns our cities - and why this urban takeover should concern us all (2015).

27. Boris Johnson, “A Manifesto for Public Space,” London government (2009).

28. Michel Foucault, Robert Castel, Jacques Donzelot, Jean-Paul de Gaudemar, Claude Grignon and Francine Muel, Espacios de Poder (Madrid: La Piqueta, 1981). 
human rights." 29 Many cities are failing on providing qualitative public spaces and responding to people's diversity in engaging with such spaces.

\section{Concluding, the Post-public Space}

The current scale of this mechanism is altering the historic meaning of the city. Therefore, corporations using POPS regulations are transforming the urban landscape. It is simple, what was small and/or public, now is becoming large and private. Small properties, local shops, public parks and squares are being crossed by large shopping malls, commerce chains, high-value housing which many times has huge footprints. Rather than creating or providing spaces to include people from diverse backgrounds and cultures (New York, London, Madrid, Paris, Tokyo), local governments and private developers are expelling people to their peripheries. ${ }^{30}$ This homogeneous urban landscape is directed towards a certain group of people: consumers. Cities need different types of spaces, but these POPS are identical for using generally grey seats, fixed tables, puny birch, espaliered trees, long rows of dark granite benches, or mini amphitheatres and stairs; POPS are being designed under these architectural and legal rules and regulations worldwide. Gradually, new different flanks have been opened where public spaces do not meet the requirements of the city of the XXI century. In fact, several important questions are opened now that challenge the current status of this new urban landscape. Who should design the public spaces of the city? Which are the potentials that should generate public urban architecture? Should public spaces be designed at all? How could a public space be measured as an accurate public space? Could the private sector participate in the provision of public spaces without really losing the sense of public? Do these spaces depend on the achievements of democracy and social equality within the availability of urban public spaces? Is it possible to universalize the features that a public space should take no matter where they are located? Are the temporary and informal public spaces the ones that propose an innovative use of the city? Whether a public space is publicly or privately owned, it must serve the city and its inhabitants' needs. Whether there is a space for public protest or not, it does not mean there is a common denominator in urban design because protestors take places for protesting. They do not go to places that are designed for such purposes because basically, there are none. However, it is important that citizens have the ability to enact their right to protest or gather in an assembly, which contrasts to POPS state as they include control and surveillance; they block protests or any kind of disobedient actions and instead they promote passive activities. POPS have become popular urban regulations in cities worldwide after 2011, provoking a homogenization in the urban landscape and

29. David Harvey, Rebel Cities. From the right to the city to the urban revolution (London \& New York: Verso, 2012).

30. Anna Minton, Ground Control: fear and happiness in the twenty-first-century city (London: Penguin, 2009). 
a loss of local history and social dynamics. Therefore, it is important to take into account that public spaces, of public or private property, have to serve social needs. They must be spaces people can live in and inhabit freely and constantly.

In a kind of ironic statement during the Occupy Wall Street protest, Mayor Bloomberg said: "Now they will have to occupy the space with the power of their arguments." "Thus, there have to be places where people can push their political rights and speak their minds. This is really the heart of why public spaces are so contentious, precisely because there have to be different kinds of spaces. In her book "The Shifting Meaning of the Urban Condition," Saskia Sassen indicates that in order to develop an urbanism that is the equivalent of the open source urbanism, architectural practices are the ones that face the urban problematic and its unusual spaces. ${ }^{32}$ By detecting, creating, intervening, and making, temporal architectural spatial practices could develop common spatial tools that extrapolate the activation of post-public spaces. Erik Swyngedouw calls for a "reworking [of] the 'creative' city as agonistic urban space rather than limiting creativity to the musings of the creative class.",33

It is a reconceptualization of how urban public spaces should accommodate the heterogeneous approaches and uses of them. In this situation, the post-public space is presented itself as a generator of publicness: the simultaneous production of contemporary public space involving and transcending technical decisions and design, financing and management. It operates at a variety of scales that overlap and intersect in order to create a mosaic of spaces and degrees of uses in a multi-layered space: physically, virtually, legally, and politically.

\section{Bibliography}

Dimmer, Christian. "Changing Understanding of New York City's Privately Owned Public Spaces." SUR (2013): 8.

Foucault, Michel, Robert Castel, Jacques Donzelot, Jean-Paul de Gaudemar, Claude Grignon and Francine Muel. Espacios de Poder [Spaces of Power.] Madrid: La Piqueta, 1981.

Glancey, Jonathan. "It's a jumble out there." The Guardian. 3 November 2003.

Harvey, David. Rebel Cities. From the right to the city to the urban revolution. London \& New York: Verso, 2012.

Kayden, S. Jerold. The New York City Department of City Planning. Privately Owned Public Space: The New York City Experience. New York: John Wiley \& Sons, Inc, 2000.

31. Ishaan Tharoor, On Scene: The Night the Police Cleared Occupy Wall Street (2011).

32. Sassen, "The Shifting Meaning of the Urban Condition," Open, no. 11 (2006).

33. Erik Swyngedouw, "The Antinomies of the Postcolonial City: In Search of a Democratic Politics of Environmental Production," International Journal of Urban and Regional Research, no. 33 (2009): 601-20. 
Koksal, Isabelle. "Activist Intervention: Walking in the City of London." In Occupy! A Global Movement. Edited by Jenny Pickerill, John Krinsky, Graeme Hayes, Kevin Gillan and Brian Doherty. Oxon: Routledge, 2015.

Minton, Anna. Ground Control: fear and happiness in the twenty-first-century city. London: Penguin, 2009.

Planning, Department of City. Zoning Resolution. New York, 2015.

POPS. “APOPS, Advocates for Privately Owned Public Space.” APOPS. 2012. htpp:// apops.mas.or/about/ [Accessed 2014].

Sassen, Saskia. "The Shifting Meaning of the Urban Condition." Open, no. 11 (2006). Who owns our cities - and why this urban takeover should concern us all. 2015. http://bit.ly/1TbMG67 [Accessed 2015].

Swyngedouw, Erik. "The Antinomies of the Postcolonial City: In Search of a Democratic Politics of Environmental Production." International Journal of Urban and Regional Research, no. 33 (2009): 601-20.

Tharoor, Ishaan. On Scene: The Night the Police Cleared Occupy Wall Street. 2011. http://ti.me/2h3mDpt [Accessed 2013].

Williams, Ryan. New Obstacles for Occupy Chicago? 2011. http://bit.ly/2vV4j15 [Accessed 2014].

\section{Websites}

Austin, Drew. Overprogrammed Cities. 2012. http://bit.ly/2h5FNeA [Accessed 2014].

Colvin, Naomi. "Occupy Activist." The Guardian, 11 June 2012. http://bit.ly/1t2xdYQ [Accessed January 2016].

Glancey, Jonathan. "Pull it down!” The Guardian, 3 April 2003. http://bit.ly/2xmyKUI [Accessed January 2016].

Johnson, Boris. “A Manifesto for Public Space.” London government. 2009. http://bit. 1y/2xAXt8C [Accessed March 2014].

Khalek, Rania. 12 Most Absurd Laws Used to Stifle the Occupy Wall St. Movement Around the Country. 2011. http://bit.ly/2h5vIhv [Accessed 2014].

Lincoln Center, David Rubenstein Atrium. http://bit.ly/2xm1Eo0 [Accesed January 2016].

Reynolds, Francis. After Zuccotti Park: Seven Privately Owned Public Spaces to Occupy Next. http://bit.ly/2jrsMMX [Accessed February 2014].

The Capital, Cairo. http://thecapitalcairo.com/ [Accessed October 2015].

Wolfe, Charles. When Policy is Defied: Occupy Wall Street and the Shapes of Avoidance. 2011. http://theatln.tc/2y0f06w [Accessed June 2015].

Woodward, Douglas. Rules of Conduct. 2012. http://bit.ly/2fkwP9q [Accessed February 2014].

WQXR, An Atrium Gets an Extreme Makeover. http://bit.ly/2jrDy5L[Accessed January 2016]. 